\title{
Faunal patterns in Tuscan archipelago butterflies: The dominant influence is recent geography not paleogeography
}

\author{
LEONARdo DAPPORTO ${ }^{1}$ and AlessANDro CINI ${ }^{2}$ \\ ${ }^{1}$ Istituto Comprensivo Materna Elementare Media Convenevole da Prato, via $1^{\circ}$ Maggio 40, 59100 Prato, Italy; \\ e-mail: leondap@gmail.com \\ ${ }^{2}$ Museo di Storia Naturale e del Territorio dell’Università di Pisa, via Roma 79, 56011 Calci, Pisa, Italy
}

Key words. Lepidoptera, butterflies, Tuscan archipelago, Tuscany, Corsica, richness, isolation, faunal composition, island area, Pleistocene, recent geography

\begin{abstract}
The aim of this paper is to examine whether current and/or Pleistocene geography affect the species richness and composition of Tuscan archipelago butterflies. This archipelago is located between Tuscany (Italy) and Corsica (France). Faunistic data was obtained from the literature and surveys. Our data revealed that contemporary geography is the most important factor determining the species richness and faunal composition of Tuscan archipelago butterflies. Indeed, current area and isolation of the islands are the only predictors significantly correlated with species richness. Paleogeographic features of the archipelago are not significantly correlated with species richness. Multidimensional scaling revealed patterns similar to those reported for other living groups. Specifically, Capraia and Montecristo group together with Corsica, while Elba, Giglio, Pianosa, Gorgona, Giannutri and the fossil island of Monte Argentario group with the Tuscan mainland. Recent geography seems to affect the faunal composition. Indeed Mantel test indicates that the similarity in the faunal composition of the Tuscan Archipelago islands is mainly related to present-day island characteristics and their relative distance from Tuscany and Corsica. Our results are similar to those recently obtained for Aegean archipelago butterflies.
\end{abstract}

\section{INTRODUCTION}

Recently, many studies have been carried out on the biogeography of the Mediterranean basin, mainly focussing on whether ecological factors or paleogeographic history dominate species richness and distribution in Mediterranean archipelagos (Palmer et al., 1999; Welther-Schultes \& Williams, 1999; Dennis et al., 2000; Garcia-Barros et al., 2002; Sammartín, 2003; Gentile \& Argano, 2005; Hausdorf \& Hennig, 2005). Several studies have investigated these topics in the main Mediterranean islands (Legakis \& Kypriotakis, 1994; Palmer, 1998), the Aegean archipelago (Sfenthourakis, 1996; Dennis et al., 2000; Hausdorf \& Hennig, 2005) and Balearic Islands (Palmer et al., 1999; Garcia-Barros et al., 2002).

The Tuscan archipelago is comprised of seven main islands lying between Corsica and the Italian Peninsula (Fig. 1). The paleogeographic events that have occurred since the Miocene, and the different present-day distances between these islands and the coasts of Corsica and Tuscany (Italy), have resulted in a transitional fauna and flora; the co-occurrence of continental species and Sardinian and Corsican endemic species therefore present an interesting puzzle (Società Italiana di Biogeografia, 1974; Jutzeler et al., 1996; Dapporto et al., 1999; 2002, 2003; Strumia, 2003). Most of these authors linked the biogeographical features of the Tuscan archipelago fauna and flora to paleogeographic events that occurred with the disjunction and rotation of the Corsica-Sardinia microplate (Alvarez, 1972) and the earlier Pleistocene sea regressions (Bossio et al., 2000). According to the most recent paleogeographical reconstructions, the lower sea level during the Würm Pleistocene glacial maxima resulted in Elba, Pianosa, Giannutri and possibly Giglio becoming connected with mainland Tuscany (Fig. 1). Capraia, Gorgona and Montecristo remained isolated, but Montecristo was very close to the little peninsula that emerged south of Pianosa (Fig. 1). On the other hand, previous Pliocene sea transgressions resulted in the isolation of several present-day mainland mountains (Lanza, 1984). To date, such fossil islands as Monte Argentario and Uccelina Hills share several biotic characteristics with Corsica and the Tuscan archipelago (Società Italiana di Biogeografia, 1974; Lanza, 1984; Dapporto et al., 2002; Gentile \& Argano, 2005).

Many studies have attempted to find similarities between Tuscan islands and their main source pools (Tuscany and Corsica). The general pattern of similarity in faunistic and floristic associations led to the association of Capraia and Montecristo, which never were a part of mainland Tuscany, with Corsica and Sardinia; while Elba, Pianosa, Giglio and Giannutri, which were in contact with Tuscany during the Pleistocene, are generally more similar to the Italian Peninsula (Società Italiana di Biogeografia, 1974; Jutzeler et al., 1996; Dapporto et al., 2003, 2004, in press; Strumia, 2003, Strumia \& Scaramozzino, 2004). Surprisingly, very few studies (Dapporto et al., 2004, in press; Strumia \& Scaramozzino, 2004) have attempted to assess this quantitatively. As a result, paleogeography has generally been accepted as the key factor leading to the species assemblages on this archipelago, 


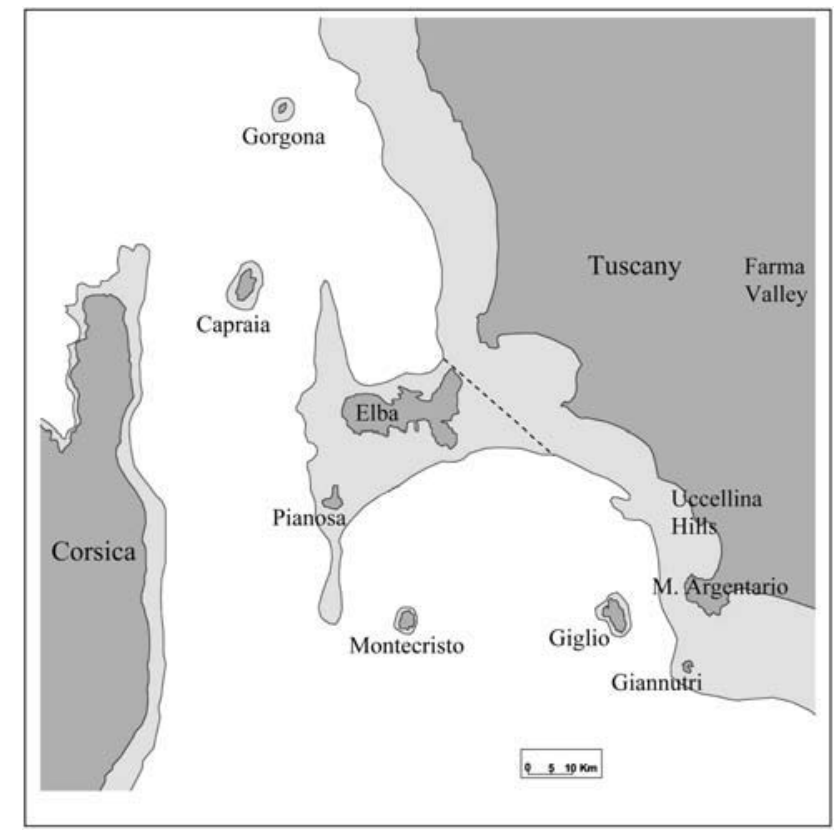

Fig. 1. Tuscan archipelago. Present-day dry land (dark grey) and extent of Würm landmasses (areas delimited by present 100 $\mathrm{m}$ bathymetric contour, light grey) (modified from Bossio et al., 2000). The broken line defines the peninsula used in the Pleistocene correlation analyses (see methods).

not only for sedentary species (Giusti, 1977; Gentile \& Argano, 2005) but also for those capable of flying (Jutzeler et al., 1996; Strumia, 2003).

Recently, Dennis et al. (2000) and Hausdorf \& Hennig (2005) demonstrated that the Aegean archipelago butterfly richness, frequency, rarity and incidence are mainly affected by contemporary geography rather than paleogeography. These authors found stronger correlations between these features of the butterfly fauna and contemporary geographical (island area, altitude, present day inter-islands distances, and isolation) than paleogeographical parameters. Similar conclusions have been drawn about the butterfly fauna of the British Islands (Dennis et al., 1997, 1998).

In this paper, the diversity of Tuscan archipelago butterfly fauna is examined and the effect of geographical and historical influences on its species richness and composition compared. In addition, the Tuscan archipelago fauna is compared with those of mainland Corsica and Italy in a search for faunistic similarities and to determine whether colonization from these two sources of fauna acted in historical or ecological time.

\section{MATERIAL AND METHODS}

\section{Study area}

The Tuscan archipelago (Fig. 1) consists of seven islands located between Corsica and Tuscany. These islands range in size from Gorgona $\left(2.2 \mathrm{~km}^{2}\right)$ to Elba $\left(223.5 \mathrm{~km}^{2}\right)$ (Table 1). The islands have different lithologies and geological origins. Gorgona is characterized by two different metamorphic units (sedimentary and ophiolitic). The volcanic Island of Capraia originated approximately nine million years ago, after a series of eruptions. Montecristo is entirely granite, as is almost the entire Giglio Island. Elba is mountainous in its western part, with the granite massif of Mt. Capanne (the highest peak of the archipelago, $1018 \mathrm{~m}$ ), whereas in the eastern part, gneiss and marble are exposed; the plains of the densely populated central area are alluvial and made up of clay, sandstone and limestone. The origin of Pianosa is different again: totally flat, it consists of sedimentary rocks and shell formations. Giannutri is formed entirely of dolomitic-limestone sediments which are similar to the rocks of the nearby Argentario fossil island.

The climate of the Tuscan archipelago is typically Mediterranean. The climax vegetation was probably oak (Quercus ilex) forests now drastically reduced to scattered patches. The present-day dominant vegetation are maquis, garigue and anthropic landscape and vegetation.

\section{Data sources}

The butterfly faunas of the Tuscan archipelago (reviewed by Biermann, 2003; Balletto et al., 2005), Corsica (Karsholt \& Razowsky, 1996), the fossil island of Monte Argentario (Biermann, 2003; Balletto et al., 2005) and the Mediterranean area of Tuscany (Balletto et al., 2005; Dapporto et al., 2005a, b) were considered. The fauna of M. Argentario fossil island was included, as it is well known that at least some moths typical of Corsica and Tuscan archipelago are present on Tuscan fossil islands. In a recent paper Gentile \& Argano (2005) also included faunas from Tuscan fossil islands in their faunistic analyses of isopods from Mediterranean islands. The Tuscan archipelago is surely the most investigated island area of Italy for butterflies and many papers report data for these insects from the beginning of 1900 s. However, to verify the completeness of this data Malaise traps were used to capture insects on each island of Tuscan archipelago, M. Argentario, Corsica and Mediterranean area of Tuscany for a minimum of two years; at least three collections of butterflies were made with a net between May 2002 and July 2006 at all the localities. It was not possible to put Malaise traps on Giannutri island as it is private, so only the data of Biermann (2003) and the results of five net collections, made over the period May 2003 to July 2006, were used.

In the search for correlations between species richness and some recent and paleogeographical determinants, the butterfly faunas from the seven islands and M. Argentario were considered. The species $(S)$ included in the analyses are listed in table 1. Butterfly species were classified as: (C) Corsican (i.e. occurring on Corsica, but not in Tuscany), (T) Tuscan (i.e. occurring in Tuscany but not on Corsica) and (W) Widespread (i.e. occurring both on Corsica and in Tuscany).

\section{Correlations between species richness and recent and paleo- geographical determinants}

Using maps in Bossio et al. (2000), the current area and isolation of each island $\left(\mathrm{A}_{\mathrm{r}}, \mathrm{I}_{\mathrm{r}}\right)$ and that during the Würm Pleistocene sea regression $\left(A_{p}, I_{p}\right)$ were measured (Table 1). As Elba, Giannutri, Pianosa and M. Argentario were connected to the Italian mainland during the Pleistocene, the Ap values of the area of the peninsula (delimited by the broken line in Fig. 1) made up of Elba and Pianosa during the Pleistocene were used. This simplification did not affect the results as this measure is the largest (Table 1) and absolute values do not affect Spearman correlations. The isolation measures $\left(\mathrm{I}_{\mathrm{r}}\right.$ and $\left.\mathrm{I}_{\mathrm{p}}\right)$ of the minimal sums of distances across the sea connecting each island to the closest faunal source pool (Tuscany or Corsica) was used. This measure was chosen instead of direct distances because, in general, butterflies disperse faster across land than sea. To estimate the correlation between the four geographical and paleogeographical variables (test of independence) and between them and species 
TABLE 1. Butterfly richness $(S)$, recent and Pleistocene island area $\left(A_{\mathrm{r}}, A_{\mathrm{p}}\right)$ and isolation $\left(I_{\mathrm{r}}, I_{\mathrm{p}}\right)$ of each of the eight islands studied. Species recorded on the Tuscan islands. Species type: $\mathrm{W}=$ widespread, $\mathrm{T}=$ Tuscan, $\mathrm{C}=$ Corsican. Asterisks indicate new records for Tuscan islands.

\begin{tabular}{|c|c|c|c|c|c|c|c|c|c|}
\hline & Type & $\begin{array}{c}\text { Gorgona } \\
(\mathrm{Go})\end{array}$ & $\begin{array}{c}\text { Capraia } \\
(\mathrm{Ca})\end{array}$ & $\begin{array}{l}\text { Elba } \\
(\mathrm{El})\end{array}$ & $\begin{array}{c}\text { Pianosa } \\
(\mathrm{Pi})\end{array}$ & $\begin{array}{c}\text { Giglio } \\
\text { (Gi) }\end{array}$ & $\begin{array}{c}\text { Montecristo } \\
\text { (Mo) }\end{array}$ & $\begin{array}{l}\text { Giannutri } \\
\text { (Gia) }\end{array}$ & $\begin{array}{l}\text { M. Argen- } \\
\text { tario (Ar) }\end{array}$ \\
\hline $\bar{S}$ & & 14 & 21 & 54 & 16 & 31 & 9 & 10 & 44 \\
\hline$A_{\mathrm{r}}(\mathrm{Kmq})$ & & 2.2 & 19.5 & 223.5 & 10.3 & 21.2 & 10.4 & 2.4 & 60.3 \\
\hline$I_{\mathrm{r}}(\mathrm{Km})$ & & 33.3 & 25.6 & 8.9 & 22.2 & 14.4 & 47.8 & 13 & 0 \\
\hline$A_{\mathrm{p}}(\mathrm{Kmq})$ & & 24 & 48 & 1700 & 1700 & 42 & 48 & 1700 & 1700 \\
\hline$I_{\mathrm{p}}(\mathrm{Km})$ & & 13 & 12 & 0 & 0 & 7 & 12 & 0 & 0 \\
\hline Carcharodus alceae Esper & W & 0 & 0 & 1 & 1 & 1 & 0 & 0 & 1 \\
\hline Carcharodus floccifera Zeller & $\mathrm{T}$ & 0 & 0 & 0 & 0 & 1 & 0 & 0 & 0 \\
\hline Spialia sertorius Hoffmannsegg & $\mathrm{W}$ & 0 & 0 & 1 & 0 & 0 & 0 & 0 & 0 \\
\hline Pyrgus armoricanus & W & 0 & 0 & 1 & 0 & 0 & 0 & 0 & 0 \\
\hline Thymelicus lineola Ochsenheimer & $\mathrm{W}$ & 0 & 0 & 0 & 0 & 0 & 0 & 0 & 1 \\
\hline Thymelicus sylvestris Poda & $\mathrm{T}$ & 0 & 0 & 0 & 0 & 0 & 0 & 0 & 1 \\
\hline Thymelicus acteon Rottemburg & $\mathrm{T}$ & 0 & 0 & 1 & 0 & 0 & 0 & 0 & 1 \\
\hline Ochlodes venata Bremer \& Grey & $\mathrm{T}$ & 0 & 0 & 0 & 0 & 0 & 0 & 0 & 1 \\
\hline Gegenes pumilio Hoffmannsegg & $\mathrm{T}$ & 0 & 0 & 1 & 0 & 0 & 0 & 0 & 0 \\
\hline Gegenes nostrodamus Fabricius & $\mathrm{T}$ & 0 & 0 & 1 & 0 & 0 & 0 & 0 & 0 \\
\hline Iphiclides podalirius Linnaeus & $\mathrm{W}$ & 0 & 0 & 1 & 0 & 1 & 0 & 0 & 1 \\
\hline Papilio machaon Linnaeus & W & 1 & 1 & 1 & 1 & 1 & 0 & 0 & 1 \\
\hline Leptidea sinapis Linnaeus & $\mathrm{W}$ & 0 & 0 & 1 & 0 & 0 & 0 & 0 & 1 \\
\hline Anthocharis cardamines Linnaeus & $\mathrm{W}$ & 0 & 0 & 1 & 0 & 0 & 0 & 0 & 0 \\
\hline Euchloe ausonia Hübner & W & 0 & 0 & 1 & 0 & 0 & 0 & 0 & 1 \\
\hline Aporia crataegi Linnaeus & $\mathrm{T}$ & 0 & 0 & 0 & 0 & 0 & 0 & 0 & 1 \\
\hline Pieris brassicae Linnaues & W & 1 & 1 & 1 & 0 & 1 & $1^{*}$ & 0 & 1 \\
\hline Pieris rapae Linnaeus & $\mathrm{W}$ & 1 & 1 & 1 & 1 & 1 & 1 & $1 *$ & 1 \\
\hline Pieris napi Linnaeus & $\mathrm{W}$ & 1 & 0 & 1 & 0 & 0 & 0 & 0 & 1 \\
\hline Pieris mannii Mayer & $\mathrm{T}$ & 0 & 0 & 0 & 0 & 0 & 0 & 0 & 1 \\
\hline Pontia daplidice Linnaeus/edusa Fabricius & $\mathrm{W}$ & 0 & 1 & 1 & 1 & 1 & 0 & $1 *$ & 1 \\
\hline Colias croceus Fourcroy & W & 1 & 1 & 1 & 1 & 1 & 1 & $1^{*}$ & 1 \\
\hline Colias alfacariensis Ribbe & W & 0 & 0 & 1 & 0 & 0 & 0 & 0 & 0 \\
\hline Gonepteryx rhamni Linnaues & W & 0 & 0 & 1 & 0 & 0 & 0 & 0 & 1 \\
\hline Gonepteryx cleopatra Linnaeus & W & 0 & 1 & 1 & $1^{*}$ & 1 & 0 & $1^{*}$ & 1 \\
\hline Lycaena phlaeas Linnaeus & $\mathrm{W}$ & 0 & 1 & 1 & 1 & 1 & 0 & 0 & 1 \\
\hline Neozephyrus quercus Linnaues & $\mathrm{T}$ & 0 & 0 & 1 & 0 & 0 & 0 & 0 & 1 \\
\hline Callophrys rubi Linnaeus & W & 0 & 0 & 1 & 0 & 0 & 0 & 0 & 0 \\
\hline Satyrium ilicis Esper & $\mathrm{T}$ & 0 & 0 & 1 & 0 & 0 & 0 & 0 & 1 \\
\hline Lampides boeticus Linnaeus & W & 1 & 1 & 1 & 0 & 1 & $1^{*}$ & 0 & 1 \\
\hline Leptotes pirithous Linnaeus & W & 1 & 1 & 1 & $1^{*}$ & 1 & $1^{*}$ & $1 *$ & 0 \\
\hline Celastrina argiolus Linnaeus & $\mathrm{W}$ & 1 & 1 & 1 & 0 & 1 & 0 & 0 & 1 \\
\hline Glaucopsyche alexis Poda & W & 0 & 0 & 1 & 0 & 0 & 0 & 0 & 1 \\
\hline Plebeius corsica Tutt & $\mathrm{C}$ & 0 & 0 & 1 & 0 & 0 & 0 & 0 & 0 \\
\hline Aricia agestis Denis \& Schiffermüller & W & $1^{*}$ & 0 & 1 & 1 & 1 & 0 & $1 *$ & $1^{*}$ \\
\hline Polyommatus escheri Hübner & $\mathrm{T}$ & 0 & 0 & 0 & 0 & 1 & 0 & 0 & 1 \\
\hline Polyommatus icarus Rottemburg & $\mathrm{W}$ & 0 & 1 & 1 & 1 & 1 & 0 & 0 & 1 \\
\hline Polyommatus bellargus Rottemburg & $\mathrm{T}$ & 0 & 0 & 0 & 0 & 1 & 0 & 0 & 0 \\
\hline Argynnis paphia Linnaeus & W & 0 & 0 & 1 & 0 & 1 & 0 & 0 & 0 \\
\hline Argynnis pandora Denis \& Schiffermüller & $\mathrm{W}$ & 0 & 0 & 1 & 0 & 1 & 0 & 0 & 0 \\
\hline Issoria lathonia Linnaeus & W & 0 & 0 & 1 & 0 & 1 & 0 & 0 & 0 \\
\hline Vanessa atalanta Linnaeus & $\mathrm{W}$ & 1 & 1 & 1 & 1 & 1 & 1 & $1^{*}$ & 1 \\
\hline Vanessa cardui Linnaeus & W & $1^{*}$ & 1 & 1 & 1 & 1 & 1 & $1^{*}$ & 1 \\
\hline Inachis io Linnaeus & W & 0 & 0 & 1 & 0 & 1 & 0 & 0 & 0 \\
\hline Aglais urticae Linnaeus & $\mathrm{W}$ & 0 & 0 & 1 & 0 & 0 & 0 & 0 & 0 \\
\hline Polygonia c-album Linnaeus & W & 0 & 0 & 1 & 0 & 0 & 0 & 0 & 0 \\
\hline Polygonia egea Cramer & $\mathrm{W}$ & 0 & 0 & 0 & 0 & 0 & 0 & 0 & 1 \\
\hline Nymphalis polychloros Linnaeus & $\mathrm{W}$ & 0 & 0 & 1 & 0 & 0 & 0 & 0 & 0 \\
\hline Melitaea cinxia Linnaeus & $\mathrm{T}$ & 0 & 0 & 1 & 0 & 0 & 0 & 0 & 0 \\
\hline Melitaea phoebe Denis \& Schiffermüller & $\mathrm{T}$ & 0 & 0 & 0 & 0 & 0 & 0 & 0 & 1 \\
\hline Melitaea didyma Esper & $\mathrm{T}$ & 0 & 0 & 1 & 0 & 0 & 0 & 0 & 1 \\
\hline Melitaea athalia Rottemburg & $\mathrm{T}$ & 0 & 0 & 1 & 0 & 0 & 0 & 0 & 1 \\
\hline Limenitis reducta Staudinger & $\mathrm{W}$ & 0 & 0 & 1 & 0 & 1 & 0 & 0 & 1 \\
\hline Charaxes jasius Linnaeus & W & $1^{*}$ & 1 & 1 & $1^{*}$ & 1 & 0 & $1^{*}$ & 1 \\
\hline Pararge aegeria Linnaeus & $\mathrm{W}$ & 0 & 0 & 1 & 0 & 1 & 1 & 0 & 1 \\
\hline Lasiommata megera Linnaeus & $\mathrm{T}$ & 1 & 0 & 1 & 1 & 1 & 0 & 0 & 1 \\
\hline Lasiommata paramegera Hübner & $\mathrm{C}$ & 0 & 1 & 0 & 0 & 0 & 1 & 0 & 0 \\
\hline Coenonympha corinna Hübner & $\mathrm{C}$ & 0 & 1 & 0 & 0 & 0 & 0 & 0 & 0 \\
\hline Coenonympha elbana Staudinger & $\mathrm{T}$ & 0 & 0 & 1 & 0 & 1 & 0 & 1 & 1 \\
\hline Coenonympha pamphilus Linnaeus & W & 0 & 0 & 1 & 0 & 0 & 0 & 0 & 1 \\
\hline Pyronia tithonus Linnaeus & $\mathrm{W}$ & 0 & 0 & 1 & 0 & 0 & 0 & 0 & 1 \\
\hline Pyronia cecilia Vallantin & W & 0 & 1 & 1 & $1^{*}$ & 1 & 0 & 0 & 1 \\
\hline Maniola jurtina Linnaeus & $\mathrm{W}$ & 0 & 1 & 1 & 1 & 1 & 0 & 0 & 1 \\
\hline Melanargia galathea Linnaeus & $\mathrm{W}$ & 0 & 0 & 0 & 0 & 0 & 0 & 0 & 1 \\
\hline Hipparchia neomiris Godart & $\mathrm{C}$ & 0 & 1 & 1 & 0 & 0 & 0 & 0 & 0 \\
\hline Hipparchia aristaeus Bonelli & $\mathrm{C}$ & 1 & 1 & 1 & 0 & 1 & 0 & 0 & 0 \\
\hline Hipparchia statilinus Hufnagel & $\mathrm{T}$ & 0 & 0 & 1 & 0 & 0 & 0 & 0 & 1 \\
\hline
\end{tabular}


richness, nonparametric Spearman correlation tests were performed. The relative importance of recent and paleogeographic factors for species richness ( $\mathrm{S}$ ) was assessed by performing a stepwise multiple regression. $S, A_{r}, I_{r}, A_{p}$ and $I_{p}$ were log transformed to match the assumptions of multiple regression. The Spearman correlation and multiple regression were carried out using SPSS 9.05.

\section{Faunal similarity}

The similarity of the faunas of the Tuscan islands and their source pools was assessed using Multidimensional scaling (using PAST). The Jaccard index was used as a similarity measure. The first analysis included all the species $\left(\mathrm{J}_{\mathrm{tot}}\right)$. Sfenthourakis (1996), Dennis et al. (2000) and Gentile \& Argano (2005) found that faunas of small islands are often very similar and differ to those on the nearest larger islands which cluster separately. This suggest that, at the regional scale, ecological factors (island area, isolation) are the main determinants shaping the faunal composition of islands. Particularly, widespread species may "hide" the importance of a reduced number of endemic and/or vicariant species occurring on small islands. Therefore another Multidimensional scaling was performed that focused only on $\mathrm{C}$ and $\mathrm{T}$ species similarity $\left(\mathrm{J}_{\mathrm{TC}}\right)$ and excluded widespread $(\mathrm{W})$ species.

Finally, the factors determining the similarity of the Tuscan islands was assessed by Mantel tests and partial Mantel tests using XLSTAT 2006.5. In the Mantel test, the null hypothesis is that the distances in matrix A are independent of those between the same objects, in matrix B. The partial Mantel test involves three matrices. The goal is to test the correlation between matrices A and B while controlling for the effect of matrix C (Legendre \& Legendre, 1998; see as examples for Lepidoptera Hausdorf \& Hennig, 2005; Beck et al., 2006). The influence of several island characteristics on the Jaccard similarity of the islands was assessed. The following were calculated: (i) the minimal sums of distances across the sea between islands $\left(D_{r}\right)$, (ii) the minimal sums of distances across the sea between islands in the Pleistocene $\left(\mathrm{D}_{\mathrm{p}}\right)$, (iii) the Euclidean distances between islands based on the minimal sums of distances across the sea from Tuscany and Corsica in recent $\left(\mathrm{dT}-\mathrm{dC}_{\mathrm{r}}\right)$ and (iv) Pleistocene times $\left(\mathrm{dT}-\mathrm{dC}_{\mathrm{p}}\right)$ using the formula:

$$
d T-d C=\sqrt{\left(d T_{i}-d T_{j}\right)^{2}+\left(d C_{i}-d C_{j}\right)^{2}}
$$

Where $\mathrm{dT}$ and $\mathrm{dC}$ are the minimal distances to Tuscany and Corsica of $i$ and $j$ islands.

Similarly, (v) the euclidean distances between islands based on recent area and isolation (values were standardized by $\mathrm{Z}$-scores) $\left(\mathrm{Eco}_{\mathrm{r}}\right)$ and (vi) in Pleistocene times $\left(\mathrm{Eco}_{\mathrm{P}}\right)$ were calculated.

\section{RESULTS}

\section{Faunistic data}

No unrecorded butterfly species were found on Corsica, Elba, Capraia, Giglio and in Tuscany. New data for islands are reported in Table 1. Based on these data it is apparent that our knowledge of Tuscan archipelago butterflies is adequate for a biogeographical analysis.

\section{Correlations of species richness with recent and paleogeographic determinants}

Some of the four geographical variables were related to each other. In particular, recent isolation is correlated with paleogeographic island area and isolation $\left(r_{\mathrm{s}}=\right.$ $-0.824, P=0.012$ and $r_{\mathrm{s}}=0.799, P=0.017$ respectively),
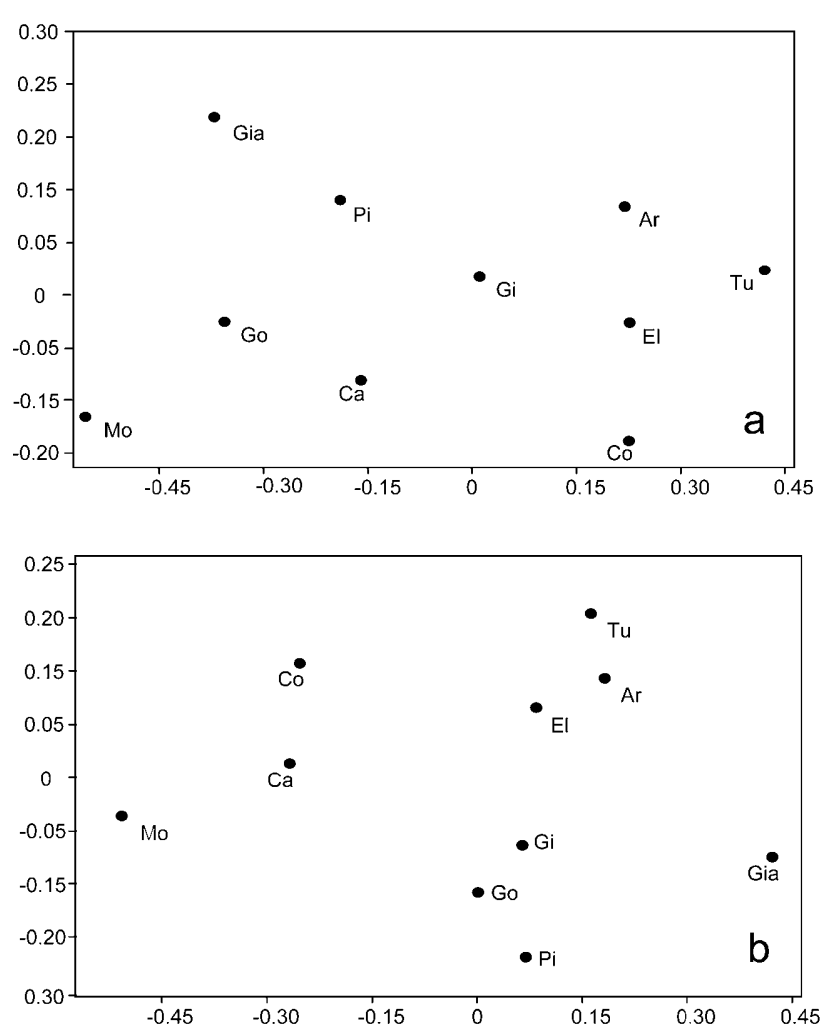

Fig. 2. Multidimensional scaling of areas based on their Jaccard index similarity matrices using presence/absence data for all the species $\left(\mathrm{J}_{\mathrm{tot}}, \mathrm{a}\right)$ and only $\mathrm{C}$ and $\mathrm{T}$ species $\left(\mathrm{J}_{\mathrm{TC}}, \mathrm{b}\right)$. Abbreviation for areas as given in Table 1 .

and paleogeographic area and isolation are also correlated $\left(r_{\mathrm{s}}=-0.865, P=0.006\right)$.

The species richness of the eight islands was most strongly correlated with recent area $\left(r_{\mathrm{s}}=0.833 ; P=\right.$ $0.010)$ and less so with recent isolation $\left(r_{\mathrm{s}}=-0.714, P=\right.$ 0.047). Furthermore, species richness was unrelated to paleogeographic island area $\left(r_{\mathrm{s}}=0.495, P=0.213\right)$ and isolation $\left(r_{\mathrm{s}}=-0.368 P=0.370\right)(n=8$ islands for each test).

Stepwise multiple regression of log-transformed data revealed that only recent island area had a positive effect ( $B=0.362, t=4.428, P=0.004)$, while recent isolation and paleogeographic area and isolation had no effect.

\section{Similarity among islands}

The two Multidimensional scaling analyses resulted in two different patterns (Fig. 2a and b). When all the species were included in the analysis the pattern in similarity showed a gradient from small and isolated islands (on the left) to large and continental ones (on the right), thus confirming the results of Dennis et al. (2000) (Fig. 2a). After removing widespread species the analysis separated the areas into two distinct blocks according to dimension 1. The first block included M. Argentario, Elba, Pianosa, Giglio, Giannutri and Gorgona together with Tuscany (on the right), the second one included Corsica, Capraia and Montecristo (on the left, Fig. 2b). The dimension 2 clearly separated the islands of the first block into two sub-groups: the first one included the large continental 
TABLE 2. Mantel tests and partial Mantel tests correlating Jaccard matrices of all species $J_{\text {tot }}$ and of $T$ and $C$ species $J_{\text {TC }}$ with geographical and ecological matrices for the islands in recent and Pleistocene times (for abbreviation see methods). In partial Mantel tests Jaccard similarities were controlled by the two matrices that were significant in the Mantel test (in bold).

\begin{tabular}{|c|c|c|}
\hline Variable & $\mathrm{J}_{\mathrm{tot}}$ & $\mathrm{J}_{\mathrm{TC}}$ \\
\hline $\mathrm{D}_{\mathrm{r}}$ & Rho $=0.144, \mathrm{P}=0.442$ & Rho $=-0.208, P=0.277$ \\
\hline Partial $D_{r}$ & Rho $=-0.150, P=0.456$ & Rho $=0.080, P=0.689$ \\
\hline $\mathrm{D}_{\mathrm{P}}$ & Rho $=0.067, P=0.729$ & Rho $=0.023, P=0.942$ \\
\hline Partial $D_{P}$ & Rho $=-0.048, P=0.820$ & Rho $=0.092, \mathrm{P}=0.625$ \\
\hline $\mathrm{Eco}_{\mathrm{r}}$ & Rho $=-0.449, P=0.017 *$ & Rho $=-0.202, P=0.301$ \\
\hline Partial $\mathrm{Eco}_{\mathrm{r}}$ & - & Rho $=-0.086, P=0.667$ \\
\hline $\mathrm{Eco}_{\mathrm{P}}$ & Rho $=-0.114, P=0.560$ & Rho $=-0.208, P=0.286$ \\
\hline Partial Ecop & Rho $=-0.068, P=0.728$ & Rho $=-0.118, P=0.550$ \\
\hline $\mathrm{dT}-\mathrm{dCr}$ & Rho $=-0.127, P=0.526$ & Rho $=-0.469, P=0.012 *$ \\
\hline Partial dT- $-\mathrm{dC}_{\mathrm{r}}$ & Rho $=0.036, P=0.863$ & - \\
\hline $\mathrm{dT}-\mathrm{d} \mathrm{C}_{\mathrm{P}}$ & Rho $=0.018, P=0.938$ & Rho $=-0.178, P=0.354$ \\
\hline Partial dT- $-\mathrm{dC}_{\mathrm{p}}$ & Rho $=0.037, \mathrm{P}=0.851$ & Rho $=0.069, \mathrm{P}=0.723$ \\
\hline
\end{tabular}

areas (Tuscany, Elba and Argentario) and the second the small and isolated islands (Gorgona, Giglio, Pianosa and Giannutri).

Accordingly Mantel tests showed a correlation between the Jaccard matrix based on all the species and the Euclidean distances in recent ecological determinants (Table 2). The Jaccard index based on $\mathrm{T}$ and $\mathrm{C}$ species is correlated only with the similarity between islands based on their contemporary position relative to Tuscany and Corsica (Table 2). Partial Mantel tests controlled for recent ecological distance and geographical position matrices for $\mathrm{J}_{\mathrm{tot}}$ and $\mathrm{J}_{\mathrm{TCr}}$ respectively, did not reveal any influence on the residuals of other recent and paleogeographic variables (Table 2).

\section{DISCUSSION}

Island area and the present-day distances from the two main faunal sources (Tuscany and Corsica) are the best predictors of species richness and distribution of Tuscan archipelago butterflies. The number of species inhabiting these islands is mostly related to recent island area and to a minor extent to the minimal distance to the nearest faunal source pool (Corsica or Tuscany). Moreover, faunal similarities depend on present-day ecological features (area and isolation) of islands and their relative distances from large faunal sources.

These results for the Tuscan archipelago may be compared with those recently reported for the Aegean archipelago, a model area for Mediterranean biogeographical studies (see Hausdorf \& Hennig, 2005 for an extensive review). However, the Tuscan archipelago consists of only seven main islands while there are a larger number of islands in the Aegean archipelago. The results obtained for the Tuscan archipelago are statistically weaker than those for the Aegean archipelago. For the Aegean archipelago, Dennis et al. (2000) and Hausdorf \& Hennig (2005) demonstrated that butterfly richness, frequency, rarity, incidence and inter-island similarities are mainly determined by contemporary geography rather than paleogeographic events. Dennis et al. (2000), in particular, demonstrated that the Aegean butterfly fauna is characterized by a decrease in diversity as island area decreases and isolation from the nearest mainland sources (Greece or Turkey) increases, which matches our result

Pianosa and Montecristo, due to their present-day location and paleogeographic history are very important for understanding the biogeography of the Tuscan archipelago. The influence of paleogeographic events should result in a high species richness on Pianosa (linked to the mainland during the Pleistocene). However, in this respect Pianosa is poorer than Elba, Giglio and Capraia and hosts only one Tuscan species compared to the 11 recorded on Elba. On the other hand, Montecristo is the only island that has dramaticaly changed its relative position with respect to Corsica and Tuscany (Fig. 1). As a consequence, if paleogeography determines the species assemblages on the Tuscan archipelago, Montecristo should have a fauna more similar to Tuscany than Corsica. The similarity between Corsica and Montecristo revealed Multidimensional scaling, reported by many other authors as well (Società Italiana di Biogeografia, 1974; Strumia, 2003; Strumia \& Scaramozzino, 2004; Dapporto et al., in press), is thus a further evidence of the influence of recent geography in determining the species assemblages on the Tuscan archipelago.

It should be noted that for Montecristo and Pianosa only two species of butterflies were used in the similarity analyses (L. paramegera for Montecristo and L. megera for Pianosa). However, the distribution of these allopatric sibling species is an important piece of biogeographic information. The distribution of the butterflies on Pianosa and Montecristo is also reflected in that of the moths. In fact, the fauna on Pianosa includes species like Dyspessa ulula Borkhausen (Dapporto et al., 1999), Menophra japygiaria O. Costa, Metachrostis velox Hübner, and Aetheria bicolorata Hufnagel (collected during this study) that are not reported from Corsica (Karsholt \& Razowsky, 1996), while only two moth species present on Corsica but not in Tuscany are reported for this island (Hyles dahlii Geyer and Lymantria atlantica Rambur, 
Dapporto et al., 1999). In contrast, the fauna of Montecristo includes several moths not present in Tuscany except on the fossil islands of Monte Argentario and Uccellina Hills (Idaea obliquaria Turati, Petrophora binaevata Mabille, Gnophos corsica Oberthür, Mniotype spinosa Chrétien, Polymixis flavicincta Denis \& Schiffermüller) (Biermann, 1990; Zilli, 1994), while only two species of moth not recorded on Corsica are reported for this island (Criphia petricolor and Noctua interposita). Finally, Pianosa is closer to Corsica than is Montecristo (Fig. 1), but because of its proximity to Elba, Pianosa is very close to the Italian mainland in terms of sea straits. On the contrary, Montecristo, is very distant both from the Tuscany coast and from Elba. Therefore, for Tuscan species Pianosa may be more easily accessible than Montecristo. This strongly suggest that butterfly colonization of the Tuscan archipelago was by dispersal from Tuscany and Corsica via Elba (as on Pianosa there are no butterfly species absent on Elba, Table 1).

Finally, the biotopes of the Tuscan archipelago islands have probably changed during historical time mainly due to intensive land use by humans. For example, the Greeks in the 5th century BC called Elba "Aethalia" (smoky) because of the smoke from the ovens used to smelt iron. Obviously the ovens were fueled by wood obtained from the ancient oak forests and when this supply of wood was exhausted the metallurgic activity moved to the vicinity of Piombino on the Tuscan mainland. Therefore, human activities could have lead to the loss of some butterfly species and improved conditions for other butterflies from Tuscany and Corsica. Human activity probably affected the natural turnover of species assemblages (e.g. by higher extinction rates and favouring colonization) which may conceal the influence of paleogeographic events on the species composition of the butterflies on the Tuscan archipelago.

ACKNOWLEDGEMENTS. This study was conducted in collaboration with the Tuscan archipelago National Park. We also wish to thank C. Cini, A. Liebert and two anonymous referees for their critical revision of the manuscript, R. Dennis for useful suggestions and encouragement, F. Strumia for managing the Malaise traps, the director and personnel of Gorgona prison for allowing us to study butterflies on the island, and the "Stazione Forestale di Follonica" for making it possible to study butterflies on Montecristo. The research was financed by a grant from the European INTERREG II-III project.

\section{REFERENCES}

Alvarez W. 1972: Rotation of the Corsica-Sardinia Microplate. Nat. Phys. Sci. 235: 103-105.

Balletto E., Monelli S. \& Cassulo L. 2005: Checklist e distribuzione della fauna italiana. 10.000 specie terrestri e delle acque interne: Insecta Lepidoptera Papilionoidea (Rhopalocera). Mem. Mus. Civ. St. Natur. Verona 16: 259-263.

Beck J., Kitching I.J. \& Linsenmair K.E. 2006: Wallace's line revisited: has vicariance or dispersal shaped the distribution of Malesian hawkmoths (Lepidoptera: Sphingidae)? Biol. J. Linn. Soc. 89: 455-468.

BiERMANN H. 1990: Beitrag zur Schmetterlingsfauna der Insel Montecristo in Toskanischen Archipel (Lepidoptera). Nachr. Entomol. Ver. Apollo 11: 179-184.
Biermann H. 2003: Tabellarische Uebersicht ueber die Tagfalter der tyrrhenischen Inseln und des angrenzenden Festlands (1. Nachtrag). (Lepidoptera, Hesperioidea, Papilionoidea) (1st supplement). Atalanta 34: 411-419.

Bossio A., Cornamusini G., Ferrandini J., Ferrandini M., Foresi L.M., Mazzanti R., Mazzei R., Salvatorini G. \& Sandrelli F. 2000: Dinamica dal Neogene al Quaternario della Corsica orientale e della Toscana. Progetto Interreg II ToscanaCorsica 1997-1999. ETS, Pisa, pp. 87-95.

Dapporto L., Cecchi B., Lo Cascio P. \& Sforzi A. 1999: Contributi alla conoscenza dell'artropodofauna dell'Isola di Pianosa (Arcipelago Toscano). II. Prima nota sui Macrolepidotteri. (Insecta, Lepidoptera). Boll. Soc. Entomol. Ital. 131: 245-252.

Dapporto L., Fabiano F. \& Nappini S. 2002: Segnalazioni di alcuni Lepidotteri rinvenuti nel Parco Naturale della Maremma e considerazioni biogeografiche. Quad. Stud. Notiz. Stor. Nat. Romag. (Suppl.) 16: 111-118.

Dapporto L., Balderi F., Biermann H., Fabiano F. \& Nappini S. 2003: New data about Heterocera of Tuscan archipelago (Insecta, Lepidoptera). Atalanta 34: 135-151.

Dapporto L., Palagi E. \& Turillazzi S. 2004: Cuticular hydrocarbons of Polistes dominulus as a biogeographic tool: a study on some populations of the Tuscan archipelago and the surrounding areas. J. Chem. Ecol. 30: 2139-2151.

Dapporto L., Fabiano F. \& Balderi F. 2005a: I Macrolepidotteri della Val di Farma. Aldrovandia 1: 37-54.

Dapporto L., Magi F. \& Strumia F. 2005b: I Macrolepidotteri dell'area boschiva e retrodunale della Riserva di S. Rossore (Pisa). Frust. Entomol. 39: 20-45.

Dapporto L., Wolf H. \& Strumia F. Recent geography determines the distribution of some flying Hymenoptera in the Tuscan Archipelago. J. Zool. (in press).

Dennis R.L.H. \& Shreeve T.G. 1997: Diversity of butterfly species on British islands: ecological influences underlying the roles of area, isolation and faunal source. Biol. J. Linn. Soc. 60: $257-275$.

Dennis R.L.H., Sparks T.H. \& Shreeve T.G. 1998: Geographical factors influencing the probability of Hipparchia semele (L.) (Lepidoptera: Satyrinae) occurring on British and Irish offshore islands. Global Ecol. Biogeogr. Lett. 7: 205-214.

Dennis R.L.H., Shreeve T.G., Olivier A. \& Coutsis J.G. 2000: Contemporary geography dominates butterfly gradients within the Aegean archipelago (Lepidoptera: Papilionidea, Hesperioidea). J. Biogeogr. 27: 1365-1383.

García-Barros E., Guerrea P., Luciáñez Cano J.M., Manguira M.L., Moreno J.C., Sainz H., SAnz M.J. \& Simón J.C. 2002: Parsimony analysis of endemicity and its application to animal and plant geographical distribution in the IberoBaleraic region (western Mediterranean). J. Biogeogr. 29: 109-124.

Gentile G. \& Argano R. 2005: Island biogeography of the Mediterranean sea: the species-area relationship for terrestrial isopods. J. Biogeogr. 32: 1715-1726.

GiUsti F. 1977: Sull'origine del popolamento malacologico dell'arcipelago toscano. Atti Soc. Ital. Sci. Nat. Mus. Civ. Stor. Nat. Milano 118: 281-284.

Hausdorf B. \& Hennig C. 2005: The influences of recent geography, paleogeography and climate on the composition of the fauna of the central Aegean Islands. Biol. J. Linn. Soc. 84: 785-795.

Jutzeler D., Biermann H. \& de Bros E. 1996: Élevage de Coenonympha corinna elbana (Staudinger, 1901) du Monte Argentario (Toscane, Italie) avec explication géologique de 
l'aire de répartition du complexe corinna (Lepidoptera: Nymphalidae, Satyrinae). Linn. Belgica 15: 332-347.

KaRsholt O. \& RazowsKy J. 1996: The Lepidoptera of Europe. Apollo Books, Stenstrup, $380 \mathrm{pp}$.

LANZA B. 1984: Sul significato biogeografico delle isole fossili con particolare riferimento all'arcipelago pliocenico della Toscana. Atti Soc. Ital. Sci. Nat. Mus. Civ. Stor. Nat. Milano 125: $145-158$.

Legakis A. \& Kypriotakis Z. 1994: A biogeographical analysis of the island of Crete, Greece. J. Biogeogr. 21: 441-445.

Legendre P. \& Legendre L. 1998: Numerical Ecology. Second English Edition. Elsevier, Amsterdam, xv $+853 \mathrm{pp}$.

PALMER M. 1998: Taxonomy, phylogeny, and biogeography of a species-group of west-Mediterranean Tentyria (Coleoptera: Tenebrionidae). Ann. Entomol. Soc. Am. 91: 260-268.

Palmer M., Pons G.X., Cambefort I. \& Alcover J.A. 1999: Historical processes and environmental factors as determinants of inter-island differences in endemic faunas: the case of the Balearic Islands. J. Biogeogr. 26: 813-823.

SANMARTín I. 2003: Dispersal vs. vicariance in the Mediterranean: historical biogeography of the Palearctic Pachydeminae (Coleoptera, Scarabaeoidea). J. Biogeogr. 30: 1883-1897.
SFENTHOURAKIS S. 1996: A biogeographical analysis of terrestrial isopods (Isopoda, Oniscidea) from the central Aegean islands (Greece). J. Biogeogr. 23: 687-698.

Società Italiana di Biogeografia (ed.) 1974: Il popolamento animale e vegetale dell'Arcipelago toscano. Atti del XX Congresso della Società Italiana di Biogeografia. Vol. 5. Lav. Soc. Ital. Biogeog.

Strumia F. 2003: New and rare Hedychridium species from Italy and Mediterranean islands (Hymenoptera, Chrysididae). Ital. J. Zool. 70: 191-198.

Strumia F. \& Scaramozzino P.L. 2004: Origine degli Imenotteri dell'arcipelago toscano in relazione alle faune della Corsica e della Toscana. Frust. Entomol. N.S. 25[2002]: 148-164.

Welther-Schultes F.W. \& Williams M.R. 1999: History, island area and habitat availability determine land snail species richness of Aegean islands. J. Biogeogr. 26: 239-249.

Zilli A. 1994: Remarks on european Myxinia species. Atalanta 25: 359-364.

Received November 9, 2006; revised and accepted February 5, 2007 